\title{
Mas afinal, o que sobrou do cinema? A querela dos dispositivos e o eterno retorno do fim.
}

Fernão Pessoa Ramos

Resumo: O que o filme faz que outras imagens móveis não fazem, quando não são filmes, é fechar-se em copas sobre a duração. Oferece ao espectador um jogo jogado. O filme é uma espécie de tanquinho que bate a matéria do tempo para poder fruí-la torcida, com emoção. Pois um filme, como uma sinfonia, passa em direção a um final que já está dado a cada instante, a cada plano. Final que existe nele e não é só 'happy end'. É sua arte de ser pela duração à diferença de uma pintura ou foto na parede. Por isso, o cinema pendurado, ou instalado, não é filme e deixa de ser cinema. É o filme que faz variar o dispositivo e não o inverso. A querela sobre o que 'restou' do cinema tem no âmago suas 'mortes' e esta espécie de grande Leviatã que é o 'cinema expandido'.

Palavras-chave: filme; morte do cinema; cinema expandido; tecnologia digital; filme e tempo; filme dispositivo.

Abstract: But after all, what's left of cinema? The film, the exhibition and the eternal return of the end - What film does have, and other mobile pictures do not (when they are not movies), is the capacity to close itself to duration. It gives its viewers a previously played game. The film is a kind of washing machine that shakes and flips the time, twisting it up and down, turning it to fruition, with emotion aiding. Film, like a symphony, must pass toward an end (a 'happy' end, says de word) that is already there, in the very start, in every plan. An end we find in the heart of its art - unlike a painting or a photo on the wall. Therefore, when we hang a film, or make it an installation, we can have whatever we want, but not film and no longer cinema. The film creates "dispositif" and not the reverse. The quarrel about what is 'left' from cinema has its heart the regressing deaths and this sort of great Leviathan that is the expanded cinema.

Keywords: film; death of cinema; expanded cinema; digital technology; film and time; dispositif. 


\begin{abstract}
$\ll-$ Je n'impose rien, juste une très modeste idée du cinema. Je voudrais seulement qu'on laisse un peu en paix le cinéma.

- Le cinéma?

- Oui, le cinéma, le vrai cinéma.»

Querelle/Raymond Bellour.
\end{abstract}

Buscaremos neste artigo delinear a situação contemporânea da arte cinematográfica levando em consideração mudanças tecnológicas que incidiram sobre o meio nos últimos trinta anos. ${ }^{1}$ Partiremos da ideia que cinema não está em todo lugar. Imaginemos por subtração: o campo da expressão artística com imagens moventes e sons é amplo, podendo ser efetivado através de dispositivos tecnológicos que se situam em espaços diversos como museus, salas de cinema, vagões de metrô, galerias, quartos de dormir. O cinema é apenas um destes dispositivos. Não se trata de estabelecer uma cadeia valorativa entre diferentes formas de expressão artística com imagens moventes e sons. Nem o cinema é igual ao universo das artes que lidam com imagens que se movem, nem o universo das artes com imagens moventes e sons a ele se restringe. Alguns desenvolvimentos em torno do conceito de 'cinema expandido' fazem equivaler cinema e o conjunto das imagens em movimento em dispositivos diversos, com prejuízo para ambos os lados.

Vamos afirmar, como argumento, a ideia do cinema restrito, "cinéma seul' como escreve Raymond Bellour, seguindo expressão de Serge Daney, ao referir-se ao período de domínio exclusivo do dispositivo cinematográfico. Ao estabelecer mediações para compreender o 'cinema sozinho' na contemporaneidade, Bellour se contrapõe

1 A proposta é dialogar com a bibliografia recente sobre o tema, particularmente polêmica no debate sobre a morte, o fim ou as transformações do cinema, face à tecnologia digital. Autores centrais e tradicionais da teoria do cinema e audiovisual debruçaram-se sobre a questão. É o caso de Jacques Aumont em Que reste-t-il du cinéma? (AUMONT, 2012) e Limites de la fiction - considérations actuelles sur l'état du cinema (AUMONT, 2014); Raymond Bellour em La Querelle des Dispositifs: cinema - instalations, expositions (BELLOUR, 2012); D.N. Rodowick em The Virtual Life of Film (RODOWICK, 2007) e L'Événement Numérique (RODOWICK, 2011); André Gaudreault em La fin du Cinéma? Un média en crise à l'ére du numerique (GAUDREAULT e MARION 2013/Papirus 2016, no prelo); François Albera e Maria Tortajada nas coletâneas Cine-Dispositives - essays in Epistemology Across Media (ALBERA e TORTAJADA, orgs, 2015); e Cinema Beyond Film - media epistemology in the modern era (ALBERA e TORTAJADA, 2000); Thomas Elsaesser em Between Knowing and Believing the cinematic dispositive after cinema (ELSAESSER, 2015) e Film Teory - an introduction through the senses (ELSAESSER, 2015). Podemos respirar o bazinismo atualizado de Dudley Andrew em What Cinema Is! (ANDREW, 2010) e Francisco Casetti apresentando um panorama ponderado em The Lumière Galaxy - seven key words for the cinema to come (CASETTI, 2015). Em horizonte temporal mais largo, há a referência do livro pioneiro de Gene Youngblood sobre a questão do cinema expandido, Expanded Cinema (YOUNGBLOOD, 1970). Philippe Dubois toma partido ao expor os limites em Oui c'est du cinéma / Yes it's cinema - Formes et espaces de l'image en mouvement/ Formes and Spaces of the Moving Image (DUBOIS, BORDINA, MONTEIRO, 2009) e também Expanded Cinema: le cinéma gagne du terrain (DUBOIS, MONVOISIN, BISERNA, 2010). Reúne seus artigos em La Question Vidéo: entre cinéma et art contemporain (DUBOIS, 2011) (parcela destes textos encontra-se traduzida na coletânea brasileira Cinéma, Vídeo, Godard (DUBOIS, 2004)). Também sobre cinema «exposto» destacamos Le Temps Exposé - le cinéma, de la salle au musée (PAINI, 2002) e o original de Jean-Christophe Royoux, Pour un cinema d'expositivion. Retour sur quelques jalons historiques (ROYOUX, 1997), que de certa forma introduz o conceito 'cinema de exposição'. No Brasil, podemos mencionar a coletânea Transcinemas, (MACIEL, 2009) e o mais antigo Pré-Cinema \& Pós-Cinema (MACHADO, 1997). 
a abordagens que giram em torno do conceito de 'cinema expandido'. Em um de seus últimos livros La Querelle des Dispositifs: cinema - instalations, expositions (2012), parece sentir-se à vontade para ressuscitar seu amigo e companheiro Serge Daney, co-fundador da revista Traffic, para debater o assunto. Retoma assim a veia forte da cinefilia francesa, na qual se sintonizam, além de Daney, autores diversos como Jacques Aumont, Jacques Rancière ou Gilles Deleuze. Na Introdução do livro (Querelle), imagina um diálogo do tipo socrático, em que retoma algumas colocações do "advogado do diabo" Serge Daney sobre o fim do cinema. É clara a necessidade de Bellour de colocar-se ativamente na 'querela' dos dispositivos. Uma vez nela, irá abordar as diferentes configurações possíveis do dispositivo cinematográfico, buscando frisar a particularidade do fílmico, mesmo em sua expressão no espaço museológico.

Bellour parte de um ponto diverso daquele que nos chega da crítica ligada à história da arte e às artes plásticas. Tem como referência o cinema propriamente dito e a especificidade de seu dispositivo, deixa de lado conceitos mais diluídos como vídeo, videoarte, miscigenação digital de mídias e intermidialidade. A novidade está em abordar o campo das instalações-cinema museológicas, a partir da própria âncora cinematográfica. Ao admitir ser o cinema uma arte essencialmente, mas não somente, tecnológica, consegue lidar com sua dimensão histórica e autoral, em contato com outras mídias. E é o que acontece com autores fortes da tradição cinematográfica. A televisão permite o trabalho cinematográfico (os filmes) de diretores clássicos como Rossellini, Bergman, Rohmer, Hitchcock, numa instigante flexão. Godard, e Glauber (com programas), também aceitam o desafio, assim como diretores ingleses como Ken Loach, Mike Leigh e outros. Para a análise, a diferença surge quando se consegue escapar da diluição metodológica que, como ameba, tudo engole no recorte da intermidialidade.

Há ainda outro horizonte no qual sentimos a abordagem de corte tecnoevolutivo, embora com maior sofisticação metodológica. Trata-se daquele resultante dos colóquios que se seguem à "descoberta" do cinema das origens, nos anos 1980 . No início do século XXI, manifesta-se na reflexão em torno de formas distintas do "dispositivo cinematográfico". Aparece, entre outros, nas coletâneas organizadas por François Albera e Maria Tortajada da Universidade de Lausanne. Thomas Elsaesser é atualmente dos pensadores mais densos da tradição cinematográfica e suas ponderações sobre o dispositivo cinematográfico podem ser situadas nesta linha (ver segunda edição, 2015, de Film Teory - an introduction through the senses). Elsaesser possui foco forte no campo da cinematografia, diferentemente das abordagens ecléticas, como as de Philippe Dubois, que pensam o fílmico com paradigmas que são da história da arte para, distendendo o horizonte "vídeo", esvaziar a gravitação do cinema. O fato é que também podemos sentir redução na reflexão que parte do 'cinema das origens' para pensar o filme. Busca-se flexionar a história do cinema a uma questão de "épistémès", linha que esboçam Albera e Tortajada em The 1900 Episteme (2010). Às "épistémès" correspondem a formas distintas de "dispositivos": a "épistémè 1900" e a "épistémè 2000" (exposta por Elsaesser em 
Between Knowing and Believing - the cinematic dispositive after cinema/ 2015a), seriam momentos que compõem, em sua amplitude de 'dispositif' (dispositivo cinematográfico), a história do cinema. Assim ela mesma (a história do cinema e seus filmes) fica meio comprimida, sem alma. Sua diversa e rica matéria estilística é reduzida, oscilando diretamente entre grandes construções conceituais, de corte foucaultiano, que são a "épistémè" e o "dispositivo". Se a estrutura funciona bem para alguns cineastas (Harun Farocki, por exemplo), revela-se de pouca operacionalidade para lidar com a amplitude estilística da tradição fílmica, sem conseguir ferramentas para lidar com a densidade do cinema-filme. A cada uma das "épistémès", que cercam o dispositivo cinematográfico, correspondem marcos discursivos/figurativos com suas próprias "arqueologias": a arqueologia da câmera, da tela, do som e da cor, da projeção e da transparência etc. A "épistémè 1900" oscila em torno da variedade da exibição e do "espetáculo" de Vaudeville, forma pioneira do cinema, ou pela desconstrução experimental do movimento (Etienne-Jules Marey); na "épistémè 2000" encontraremos a encruzilhada do cinema com o museu, o cinema instalação ou o cinema-exposição. A camisa de força que o foco nos dispositivos coloca no cinema-filme é nítida. O próprio Elsaesser a reconhece, considerando, sem deixar de lado a ironia, que o "lugar do cinema no meio digital hoje (é) como uma irritante força estabilizadora, de contraposição, ao campo expandido da interação midiática, típica da épistémè 2000" (Idem, p. 50-51).

As particularidades da forma filme podem ser descritas, o que não quer dizer que sejam ontológicas. A dominância da imagem-câmera na composição da imagem fílmica significa que, na tradição cinematográfica, um núcleo de imagens remete-se a figuras compostas na circunstância da tomada, mantendo-se principalmente a figura do ator e seu corpo. É claro que, com as tecnologias digitais, dilata-se o uso de imagens compostas inteiramente fora da tomada ou da manipulação da imagética da tomada. Mas é difícil considerar que estivesse ausente no período histórico do suporte película. Segue que o conceito de mise-en-scène (composição estilística na cena da tomada), permanece particularmente pertinente na análise fílmica. Além disso, o cinema é filme, imagem articulada por montagem, que transcorre. É pela montagem/decupagem que o cinema deixa de ser apenas cinema, amontoado de tomadas, e dá um salto qualitativo. É pela articulação consecutiva na duração (que a montagem funda) que o filme é pensado para 'passar'. É nela que se instaura a medida de seu fim (filme) e é composta sua particularidade no universo das artes e das imagens. Pois um filme, como uma sinfonia, passa em direção ao fim (passa em direção à morte) que já está dado a cada instante, a cada plano (como já via de modo preciso Pasolini). Fim que existe nele e é sua arte - à diferença de uma pintura ou foto na parede, por exemplo.

Por isso, o cinema pendurado na parede não é filme e deixa de ser cinema. O filme é o cinema em ação, por assim dizer, e a montagem é a carne de seu movimento. No momento em que filme e cinema se articulam estabelece-se a sessão: o cinema é 
o dispositivo do filme, mas o inverso não é verdadeiro. O filme é o modo particular do cinema que sem ele perde as pernas para se tornar apenas expressão com imagens em movimento e som. Pois o filme em seu fim tem um modo seu de conceituar o mundo, de expressar, e para isto necessita do dispositivo cinema. Quando o filme sai do cinema, o cinema também se retrai e se torna outra coisa, o que nos permite negar a ideia da linha evolutiva de um dispositivo variável que, em sua modulação, teria a tradição fílmica no meio. É o filme que faz variar o dispositivo, e não o inverso.

A sessão, como modo de passar do filme, é o que existe de mais particular ao cinema. É o que o particulariza dentro do conjunto das artes e dos dispositivos. A sessão como modo de passar é tão importante para a definição do filme que nos permite abandonar a tentativa de ver sua especificidade nas imagens moventes. Não é difícil imaginarmos um filme com imagens fixas (caso paradigmático de La Jetée/1962) ou imagens mudas. O importante é que estas imagens estejam articuladas (montadas) em filme, que passem, que durem, dentro da medida que é a medida do filme. Pois o filme é medida e sua medida acaba por determinar um modo de fruição que deve ser adequado à nossa resistência (mesmo física) a este passar. Digo física, pois como ver passar as vinte e quatro horas de Psicose ('24 Hour Psicho', instalação de Douglas Gordon, 1993) numa "séance"? Não há sessão, pois o filme se foi e a ideia da instalação era exatamente esta. Gordon tem má vontade com o cinema (como ele mesmo declara), mas não é por isso que o cinema não existe. Existe apenas a desconstrução que Gordon, em suas instalações, faz do cinema-filme. Como ver passar imagens de um dispositivo museológico acima de certo intervalo, certa duração? Como ver isto de pé, ou em um banco de madeira sem encosto, ou em uma almofada aberta a todo tipo de interferência luminosa, dispersão sonora. Não há como ver filme assim, pois não há sessão no visionamento aleatório, aberto para o entrar e sair do espectador num looping contínuo da imagem. Esta fruição é próxima ao universo de olhar um quadro, uma foto, uma antiga 'videoarte' (se quisermos). É a fruição de uma instalação museológica, mas não cinema.

Cinema, portanto, tem duração em dupla mão, pois ele é a partir da medida do passar do filme, apertado na sessão que corre para o fim. Há sempre um 'the end', como a narrativa clássica logo sentiu necessidade de estampar com graça. Há sempre um final, desde o início e o tempo todo. Esta é a graça do cinema e ele sabe disso. É na possibilidade do espectador experimentá-lo como fim antevisto que sua arte começa. Há um corredor estreito em face de si para passar imagens/sons que transcorrem, mas que pode se revelar infinitamente amplo: o corredor do filme. Infinitamente amplo, pois ele é capaz de mostrar o tempo comprimido e dividido da expectativa, mas também o tempo absoluto que quer conceituar ou exprimir, através do que, só ele, figura (ao menos nesta forma): fresta para além da porta da duração, o "de fora" que submerge. Há mesmo um tipo de cinema, um tipo de imagem, se seguirmos a filosofia, imagem que Deleuze descreve longamente o que chama de imagem-tempo, 
o "noosigno", que ele, o filme, se quer lá, no de-fora. Um tipo de cinema que estranha o plano de imanência onde o corpo ancora, e torce pelo pescoço do tempo o filme e sua vontade, ou sua angústia, de nele estar ancorado. É para isso que o dispositivo do cinema serve, quando filme. Para retorcer o tempo da imagem e do som no modo do passar, para potencializar em um modo muito específico este 'retorcimento' da matéria, que passa virada no lado do avesso pelo dispositivo cinema, tempo do filme.

Não podemos falar do filme e sua forma de passar sem ver que é pela emoção, pelo afeto, que ela se instaura. Para nós o que o filme faz, e outras imagens móveis não fazem, quando não são filmes, é fechar-se em copas sobre a duração, oferecendo ao espectador um jogo jogado: proposta de esticar e sacudir matéria que não existe, pois é só para nós mesmos que ela é, pelo tempo. Pois o filme faz isso, ou ele pode nos fazer ver isto, e aí está sua particularidade. Ele é uma espécie de tanquinho que bate a matéria do tempo, o movimento, para poder fruí-la torcida, como emoção. Às vezes nem o pano do movimento é necessário e a máquina do tempo produz sua própria matéria na espuma. O tempo do filme é sua essência, pois sua matéria é feita de imagens móveis de coisas, corpos, ruídos, música, fala, elementos do mundo que, por excelência, caracterizam-se no transcorrer, pelo durar.

Em algum ponto, em algum plano de imanência, talvez possamos encontrar, pelo filme, diretamente o durar, a duração. Chegaria como tela, pela fenda, diferença do sujeito, imagem pura do tempo, do Todo no qual o sujeito (menor) estaria por subtração. Esta soma será então filme, ou cinema. A medida do filme não é a do espectador, mas aquela da qual ele não escapa. É a medida do tempo que necessariamente passa, não mais por ele (ilusão), mas pelo filme. O filme tem toda a brutalidade da duração em seu modo premente de transcorrer, como um trem que não pode parar para ser (figura que Truffaut gostava de citar), ou como cachoeira, na bucólica versão tupiniquim de Humberto Mauro. E para tal, quando em sua experiência plena, deve passar num absoluto sem gradação, sem 'degradação', duração que avança como trem (ou cachoeira) numa sala escura e com imagem gigante. Experiência plena só quando em seu modo não 'corrompido', não 'degradado': imagem gigante cujo transcorrer independe da ação do espectador. Mas há também um modo 'corrompido' de ver filmes passarem em dispositivos mais práticos (tvs, celulares, computadores, mini-DVDs, etc), em situações de visionamento precárias (aviões, trens, ônibus, etc), ou 'degradadas' (luz, interrupções, desconforto, etc), mas análogas à 'experiência própria' do cinema. Raymond Bellour em Querelle (BELLOUR, 2012, p.15) desenvolve este ponto sobre 'visão degradada' do cinema. Francesco Casseti (2015) apresenta um amplo panorama das modalidades da visão fílmica degradada e seus prazeres na miríade contemporânea dos dispositivos móveis. A visão degradada é hoje, muitas vezes, acompanhada de uma audição 'refinada', mais detalhada que na sala escura, com fones de ouvidos que isolam o espectador sonoramente do mundo. 
O fator 'isolamento sonoro' potencializa a imersão, mesmo com a imagem móvel em telas reduzidas. Há uma espécie de compensação: o isolamento sonoro do mundo com fones aumenta e recupera, em outra dimensão, a amarração espectatorial originária na duração do filme, própria à 'sessão' de sala escura com isolamento visual (tela gigante e imagem transcorrendo independente).

É neste sentido que devemos compreender a arguta observação de Jacques Aumont, em Que reste-t- il du cinéma? (2012), de que a principal inovação tecnológica nas últimas décadas, a última grande inovação tecnológica do automatismo cinematográfico, não foram suporte e dispositivos digitais, mas o botão de "parar", seja no aparelho de videocassete, no reprodutor de $C D$, no computador ou no celular. Pois parar o filme não faz parte do cinema, assim como não faz parte da expressão musical, numa sinfonia, pará-la. Talvez, por isso, música e filme estejam juntos, desde os primórdios. Não se pode parar um filme, como não se pode parar um trem, ou uma cachoeira. A sessão tem este modo de correr absoluto, torcendo o rabo do tempo pela duração que corre desembalada para seu fim. Laura Mulvey (2006), Mary Ann Doane (2002), Raymond Bellour (1997), Serge Daney $(1991 ; 1993 ; 1997)$ já se debateram sobre este aspecto do filme, fechandose em círculo sem volta (pois tentar pará-lo para pensá-lo, seja na análise, significa abri-lo num modo que não se abre sem deixar de sê-lo). Casetti (2015) também apresenta algumas modalidades contemporâneas de contorno ao paradoxo do filme sem fim, sem abandonar o núcleo fílmico.

A polêmica sobre o que "restou" do cinema na contemporaneidade traz em seu âmago a questão do filme. Alguns creem poder deixá-lo para trás, nesta espécie de grande Leviatã que é o 'cinema expandido'. A noção de 'cinema expandido' tem sua genealogia no livro Expanded Cinema do norte-americano Gene Younblood (1970), imerso no quadro ideológico que respira a contracultura californiana dos anos 1960. É herdeiro de uma cosmologia do tipo hippie, baseada no pensamento do místico francês Pierre Teilhard de Chardin. Chardin, que viveu na primeira metade do século $\mathrm{XX}$, um pensador que teve sua influência nos escritos de André Bazin com sua cosmologia idealista transcendental, de fundo cristão. Viria de Chardin o conceito de 'noosfera', no qual Younblood se baseia para desenvolver sua teoria de um "cinema expandido", que alguns tentam relacionar à multiplicação digital de dispositivos pessoais. O salto é grande, como bem nota Jacques Aumont em capítulo com veio irônico de Que reste-t-il du cinéma?, intitulado "Expanded et autres rêveries" (AUMONT, 2012, pgs 44-49).

No campo francofônico, a polêmica sobre "cinema expandido" ou a "querela" do cinema-dispositivo é marcada por lados bem distintos, situando-se numa ponta Philippe Dubois (2009, 2011, entre outros) com visão mais ampla e diluída do que seria a nova dimensão "expandida", próxima do ferramental conceitual da história da arte; e de outro lado, Jacques Aumont (2012; 2014) e Raymond Bellour (2012), com perspectiva mais 
fechada, fincando posição no cinema-filme. Aparentemente, Dubois fica um pouco isolado, inclusive pelo tom mais agressivo, de manifesto, que utiliza em alguns de seus escritos. Na realidade, o diálogo de Bellour em Querelle desenvolve uma abordagem diferencial do cinema-exposição para colocar a perspectiva do cinema-filme em seu núcleo. A projeção e a sessão tornam-se conceitos-chave (projeção também entendida como tela iluminada pelo dispositivo digital). Avançando o debate, Aumont traz nuances a colocações originais presentes em Que reste-t- il du cinéma? (2012). No seu livro seguinte (2014) Limites de la Fiction - considérations actuelles sur l'état du cinéma, centrará a definição do fílmico como um dispositivo próprio, que em seu núcleo caracteriza-se pelo estatuto ficcional. A partir deste núcleo, caminha com agilidade para uma análise na qual demonstra seu domínio sobre a dimensão fílmica contemporânea, em sua diversidade estilística.

Em Que reste- $t$ - il du cinéma? Aumont traça restrições à sobredeterminação que costuma cercar abordagens da nova tecnologia digital. Um dos aspectos de tais reparos diz respeito à ênfase nas transformações resultantes da digitalização do dispositivo cinematográfico e seus efeitos na narrativa fílmica. Ao descrever tendência do cinema contemporâneo denominada "slow cinema" (Apichatpong Weerasethakul, Hou HsiaoHsien, Tsai Ming-liang, Albert Serra, Jia Zhang-ke, os Straub, Pedro Costa, Alexander Sokurov aos quais poderíamos somar diretores mineiros como Cao Guimarães, Marília Rocha, Clarissa Campolina), Aumont detecta um cinema que se abre à tensão do encontro que o plano longo determina, num sentido que não deixa de remeter a certo bazinismo reciclado. Importa, na linha de se desfazer da visão tecno-evolutiva, realçar como este cinema e estes filmes se articulam através do maquinismo digital. Neste ponto, Aumont se distancia da visão de David Rodowick em The Virtual Life of Film (2007) e por tabela também do Lev Manovich em The Langage of New Media (2001). Rodowick crê poder transformar o estatuto cinematográfico do plano longo em função das novas características tecnológicas digitais numérico/algorítmicas, buscando determinar uma posição diferencial do sujeito na tomada (e, portanto, no filme). Se a questão do ceticismo, conforme abordada por Stanley Cavell, se vislumbra no horizonte de Rodowick, e dá densidade ao argumento, desmontar a dimensão ontológica do plano longo é um passo muito largo. Análisando obras chaves da filmografia mundial deste início de século XXI podemos concluir que as determinações tecnológicas detonadas pelo processamento algorítmico da imagem não incidem de modo significativo sobre as potencialidades do plano longo e seu modo de "grudar" na duração. Também outros procedimentos estilísticos da narrativa cinematográfica caminham nesta linha. O plano extenso continua existir com sua potência de sempre, infenso, neste aspecto, ao maquinismo digital (a análise de Rodowick dialoga com a A Arca Russa de Alexander Sukorov). Como Aumont está sintonizado com as tradições fílmica e cinefílica, é a partir de tais inflexões que percebe os males do fundamentalismo tecnológico quando foge à realidade dos fatos. 
André Gaudreault faz um apanhado das polêmicas em torno da questão do dispositivo cinematográfico, enumerando posições em O Fim do Cinema? Uma mídia em crise na era digital (2016). O levantamento mostra a relação orgânica entre cinema e os diferentes maquinismos perecíveis da imagem-som, assim como sua persistência para além deles. O perigo é que, na variedade de formas maquínicas, o cinema surja como acidente de percurso. O cinema para alguns estudiosos das "origens", é um incomodo "irritante" (com bem vê Elsaesser), insistindo em aparecer quando não é chamado e perdurar além da medida que lhe cabe. A mesma lógica vigora na disposição linear de um "pré" e "pós" cinema. Em seu apanhado da querela dos dispositivos, Gaudreault estabelece um quadro cronológico das mortes recorrentes do cinema. Consegue, com certo humor, isolar oito delas. Do fim para o início (partindo de hoje em direção aos primórdios, ao cinema das origens), vai enumerando os "fins" do cinema como um movimento de retorno. A morte mais recente, vamos chamá-la de oitava morte do cinema, é marcada pela proliferação da tecnologia digital. A morte anterior, a sétima, seria aquela marcada pela banalização do controle remoto, no início dos anos 1980, maquinismo que detona e inaugura o modo espectatorial do "zapear", multiplicando o controle do espectador sobre o transcorrer da sessão e o passar do filme (que deixa de ser absoluto). É o fim do cinema-cachoeira. Serge Daney escreveu bastante sobre esta morte do cinema (1991, 1993). Se a sétima morte do cinema atinge diretamente a carne da narrativa cinematográfica em seu modo de durar, a sexta e quinta mortes do cinema relacionam-se às consequências da inovação tecnológica sobre o modo de exibição. A sexta morte é derivação direta da sétima, marcada pelo aparecimento do meio tecnológico videocassete e pela proliferação da tecnologia eletrônica, agora portátil, do vídeo. É a era do 'vídeo', da 'videoarte', das instalações explorando a novidade da simultaneidade e seus correlatos. Contexto que se instaura com um forte discurso reivindicando a morte do cinema. A proliferação do videocassete e do maquinismo vídeo portátil significaria o fim do monopólio do filme no cinema. Significaria o fim da relação intrínseca e unitária entre filme e cinema, entre filme e sala de cinema propriamente. Relação já aventada, certamente, com a televisão, mas que agora tem outra escala. Já se antevê, nesta morte, a miríade de dispositivos digitais que promovem acesso ao filme no início do século XXI.

A quinta morte do cinema, na escala de Gaudreault, vem de um baque forte, resultado da proliferação da televisão nos anos 1950. A imagem em movimento cinematográfica deixa de exercer seu monopólio com o aparecimento do dispositivo da televisão, gerando uma enxurrada de manchetes e artigos em jornais que pontificam o fim do cinema. Se ainda hoje respiramos, no discurso de alguns artistas, certo ressentimento pelo domínio de antanho do cinema-filme, o surgimento da televisão deu o primeiro fôlego para a liberação das imagens móveis do dispositivo cinema. Com a proliferação dos dispositivos "vídeo" portáteis, a disputa pela ocupação se desloca para o campo das artes. A televisão, na realidade, antes do aparecimento recente das "séries", nunca disputou o espaço 
das 'Artes' com o cinema. São as artes plásticas, a arte contemporânea, que passam, no século XXI, a trabalhar de modo cada vez mais intenso com imagens em movimento/ sons em telas maquínicas múltiplas. Deslocamento que vai da antiga "videoarte" do século XX para as instalações do "cinema-exposição" e para os museus/galerias da contemporaneidade. A elegia do formato "vídeo", a crença no conceito "vídeo" como polo aglutinador, é o último suspiro de uma trilha que virou pelo avesso com o surgimento do digital. Em alguns textos do século passado parecia que toda a história do cinema evoluía para desembocar no vídeo. Godard era um vídeo-artista que lutou a vida toda para escapar das influências retrógadas do cinema. Alguns elementos desta ideologia do antigo "vídeo" permanecem na reflexão contemporânea sobre artes digitais ou "cinema exposto", mas o quadro evidentemente é outro.

Na nova lida com a morte do cinema, o ponto é querer trazer o cinema para a área das artes contemporâneas e fazê-lo caber aí, seja reduzindo a história e a estilística do cinema, seja fazendo cinema em museus e exposições. O "cinema exposto", o cinema que "expõe" o tempo, como o define Dominique Païni (2002) seguindo trilha de Jean-Christophe Royoux (1997), aparece como trilha nova, abertura sensorial, radicalização expressiva que o cinema-filme não consegue atingir em função do limite da sessão. Na "morte" digital do cinema, o choque entre arte contemporânea e cinema eclode principalmente no final da década de 1990/2000, expondo bifurcações que já se vislumbravam desde a videoarte, nos anos 1970. A novidade no 'fim' contemporâneo é o diálogo das artes com o cinema-filme (e o tempo da sessão), pela exposição do cinema na parede, como quadro que se pendura ou instala. Segundo Païni, do espectador exige-se que seja um 'visitante', um "flaneur", que entre e saia da sala (e do transcorrer da imagem), sem a prisão espectatorial da fruição fílmica, com todos os desconfortos e limites duma visita. O cinema exposto, "pendurado" no gancho (na "cimaise") da parede do museu. expõe o tempo como percepção. A partir daí o cinema pode, segundo Païni, "jogar (agora como titular) no quintal das grandes artes contemporâneas" (PAïNI, 2002, p.67).

Alguns críticos teimam em ver um quadro excludente nesta divisão. Querem amarrar pontas de campos diversos (cinema e arte contemporânea), como experiências singulares de mesclagem. Bellour elogia o modo pelo qual Jacques Rancière, em seu livro A Fábula Cinematográfica (2013), percebe a fissura entre cinema e arte contemporânea, estabelecendo "uma clivagem fundamental persistente entre os dois regimes do cinema e a arte contemporânea" (BELLOUR, 2012, p.40). Além de reconhecer a clivagem, a oposição diferencial em Rancière traça dois campos no cinema (grosso modo, "filme" e "exposição", segundo nossa terminologia), mas considera o cinema uma "arte solteirona", que é acompanhada pela arte moderna do outro lado da rua: "Rancière parte, como outros, da ideia de que há hoje uma "dupla existência do cinema". Mas sua originalidade é de opô-las, em vez de tentar misturá-las ou estabelecer julgamento de valor sobre seus valores respectivos" (BELLOUR, 2012, p. 40). É assim que o cinema pode "permanecer 
ao largo da história da modernidade, (que é) centrada sobre a glória ou o luto da autonomia pictural" (Bellour citando Rancière, em BELLOUR, 2012, p. 40). Trata-se de abordagem para a qual Jacques Aumont converge e que ele desenvolve, como podemos verificar em seu livro Moderno? Por que o cinema se tornou a mais singular das artes (AUMONT, 2007). Existe, na realidade, no cinema, um mesmo duplo regime cinematográfico de "espacialização da ideia", regime estabelecido através de (caso "A") "experiências diretas da sensorialidade", próximas do universo das artes; ou (caso "B") "modalidades narrativas de sensorialidades, derivando especificamente do cinema" (BELLOUR, 2012, pg 40).

Podemos notar estes "regimes" em altercação se estabelecendo através da distorção do cinema e seu dispositivo, em autores fílmicos que circulam com facilidade entre espaço expositivo e filme, como Harun Farocki, Péter Forgács, Michael Snow, Peter Greenway, Cao Guimarães, Sandra Kogut, Neville D’almeida (Cosmococa Programa In Progress - Quasi-Cinema; Tabamazônica), Peter Kubelka, Chantal Akerman, Chris Marker, Agnès Varda, Apichatpong Weerasethakul, ou diretores fílmicos tradicionais que montam exposições como Godard, que claramente não vence a camisa de força do cinema-exposição no inconcluso Voyage(s) en Utopie JLG, 1946-2006, à la recherche d'un théorème perdu/Beaubourg, Abbas Kiarostami, Atom Egoyan e outros. Existe igualmente a inflexão do fílmico que coloca no centro um campo de gravidade no qual atuam as figuras dos grandes curadores museológicos, talvez tentativa de sequestrar o cinema e seus autores pela disposição curatorial museológica: Dominique Païni (Projections, les Transports de l'image e Hitchcock et l'art: coincidences fatales); PhilippeAlain Michaud (Le Mouvement des Images), Chris Dercon (Exploding Cinema/Cinema Without Walls); Joachim Jager e outros em Beyond Cinema: the Art of Projection (Hambuger Bahnhof); o próprio Bellour na pioneira (1989) Passages des Images e certamente bienais diversas, como Veneza 1999/2001, São Paulo ao longo da década de 2000, ou Documenta. Partindo do lado da rua das artes contemporâneas, encontramos artistas plásticos com carreira no universo das exposições, que desembocam no cinema para sequestrá-lo, a si e seu tempo, torcendo para erguê-lo como escultura, ou conseguir pendurá-lo na parede. O campo fílmico pode provocar indigestão, mas aí é que fica a arte e a potência de artistas como Doug Aitken, Pipilotti Rist, Douglas Gordon, Pierre Huyghes, Sam Taylor Wood, Philippe Parreno, Janet Cardiff, James Coleman, Thierry Kuntzel, Tacita Dean e outros. A diversidade de composições e seus regimes, neste conjunto amplo de artistas citados, pode, ou não, influir sobre o estatuto do filme e diluí-lo, incidindo sobre sua disposição.

Ainda na cronologia das mortes do cinema, a quarta morte para André Gaudreault, depois das decorrentes da multiplicação do dispositivo vídeo/digital e talvez a mais intensa em termos da própria arte, é a que cerca a introdução do som no final dos anos 1920. Foi também anunciada como fim, a grandes pulmões por parte de crítica cinematográfica. Ideia que se propaga no Brasil, permanecendo, em alguns casos renitentes até o fim dos anos 1940. Com o desenvolvimento pleno do cinema sonoro, muitos irão se espantar com 
a consistência expressiva do novo cinema, que agora torce a duração pelo som, incorporado na própria articulação fílmica. A terceira e segunda mortes do cinema, são menores, se assim podemos dizer. Lidam com diferenciações históricas mais específicas ao cinema das origens, caras a um historiador dos primeiros tempos como André Gaudreault. Parecem ser mortes que Gaudreault realmente leva em conta por permitirem ver o cinema-filme pela vidraça, ou lente de aumento, na variedade do dispositivo expositor/projetor. A terceira morte do cinema refere-se à fissura entre cinema, já esboço de 'narrativa', e cinematógrafo, ainda máquina de produzir imagens como atração. Ocorre no início da década de 1910. A segunda morte é relativa às mudanças no sistema de exibição e distribuição necessárias para passar cinema em sala própria, fora das feiras, dos circos, do "Vaudeville". Ocorrida entre 1907 e 1908, marca o início da produção cinematográfica em massa, com o fim da hegemonia europeia (particularmente francesa) e o domínio de estúdios e distribuidores norte-americanos. A primeira morte do cinema é aquela que o inaugura, no modo que antevê seu inventor, ao abrir-se, já neste instante, como dispositivo pelo fílmico. Configura-se por trazer, na matéria que lhe dá origem, o conteúdo de um mito pressentido. Talvez seja a mais essencial, pois mostra a face dupla de um dispositivo diverso, voltado, desde sempre, para o seu fim como superação. Está na famosa declaração de Louis Lumière, repercutida por autores diversos como George Sadoul ou Jean-Luc Godard, que o cinema é uma invenção (portanto, uma tecnologia), ou arte, "sem futuro".

O repertório das mortes traçado por Gaudreault é assumidamente livre e pessoal, mas não menos significativo. Aponta em direção à morte mais próxima: a da tecnologia digital. Embora uma mudança de paradigma tenha ocorrido, é inegável verificarmos que fim propriamente não houve, como se constata no dinamismo e diversidade da produção fílmica atual. As pessoas continuam indo ao cinema (ou vendo filme nos dispositivos portáteis) em um ritmo no qual não se vislumbra fim brusco como tendência. O cinema, através da imagem móvel, ou mesmo imóvel, mas sempre pela duração fílmica, lida com a maneira que temos de nos fincar no presente e pode manipulá-lo pela experiência espectatorial. Lida com nossa maneira fazer passá-lo, tempo presente, para adiante ou para trás, acelerado ou em vagar. Fura um buraco no passar, mas não corre como fio na agulha. Não costura. Pode acelerar, como passam duas horas que voam na duração de um filme de ação na sala escura, ou pode furar, significar, a intuição temporal em sua imanência da figuração de outro tipo de imagem (a imagem do "de fora"). Certamente a arte não está só aí, no modo que o passar do filme determina. Mas esta é sua particularidade. Arte que está em nos fazer andar para frente e para trás, apesar da âncora com pés de barro que prende nosso corpo no presente estendido, que é a vida (ou a sessão). No meio do que MerleauPonty chama de "chiasme", encontro da carne com o mundo, o filme marca um intervalo no qual este encontro se desfaz em modalidades flexíveis, em modalidades de subtração, modo de vislumbrar o virtual que veio se envolver no plano da imanência. Formas de imagem das quais o cinema, ao passar pelo filme, é apenas marca, ou pensamento/ conceito, expressão. Ao se inserir no presente estendido, no lerdo presente estendido, 
o filme e seus avatares lidam com uma forma de fazer suportar a extensão em sua monótona forma de transcorrer (Heidegger designava esta lida pelo conceito de "angústia"). É isto que faz, nos permitindo suportar a extensão no modo diferenciado do intervalo que cria. É ao intervalo que chamamos cinema, importando pouco o dispositivo tecnológico que o sustenta, desde que traga amarrado pelo rabo sua duração - como o faz o filme.

Fernão Pessoa Ramos é professor na Unicamp.

fernaopramos@gmail.com

\section{Referências}

ALBERA, Francois e TORTAJADA, Maria. The 1900 Episteme. IN: ALBERA, Francois e TORTAJADA, Maria (org.). Cinema Beyond Film - media epistemology in the modern era.

. (org.). Cine-Dispositives - essays in Epistemology Across Media. Amsterdam: Amsterdam University Press, 2015.

ANDREW, Dudley. What Cinema Is! Oxford: Blackwell, 2010.

AUMONT, Jacques. Moderno? Por que o cinema se tornou a mais singular das artes. Campinas: Papirus, 2007.

. Que reste-t-il du cinéma? Paris: Vrin, 2012.

. Limites de la fiction. Considérations actuelles su l'état du cinema. Paris, Bayard, 2014.

BELLOUR, Raymond. Entre-imagens. Campinas: Papirus, 1997.

La querelle des dispositifs: cinema - instalations, expositions. Paris: P.O.L. Editeurs, 2012.

CASETTI, Francesco. The Lumière Galaxy - seven key words for the cinema to come. Nova York: Columbia University Press, 2015.

DANEY, Serge. Devant la recrudescence des vols des sacs à main: cinéma, télévision, information. Lyon: Aleas, 1991.

. Le salaire du zappeur. Paris: POL, 1993.

Cine-Journal (Vols I e II). Paris: Cahiers du Cinéma, 1997/1998.

DOANE, Mary Ann. The emergence of cinematic time - modernity, contingency, the archive. Harvard University Press, 2002.

DUBOIS, Philippe. Cinema, Vídeo, Godard. São Paulo: Cosac Naify, 2004.

. La question vidéo: entre cinéma et art contemporain. Crisnée: Yellow Now, 2011.

DUBOIS, Philippe. MONTEIRO, Lúcia Ramos; BORDINA BORDINA, Alessandro (edit). Oui c'est du cinema/Yes, it's cinema - Formes et espaces de l'image en mouvement/Forms and Spaces of the Moving Image. Pasian di Prato: Campanotto Editores, 2009.

DUBOIS, Philippe; MONVOISIN, Frédéric; BISERNA, Elena. Expanded Cinema: le cinéma gagne du terrain. Pasian di Prato: Campanotto Editores, 2010. 
ELSAESSER, Thomas. Between Knowing and Believing - the cinematic dispositive after cinema. IN ALBERA, François; TORTAJADA, Maria (org.). Cine-Dispositives - essays in Epistemology Across Media. Amsterdam: Amsterdam University Press, 2015.

Film Theory - an introduction through the senses. Nova York: Routledge, 2015 (2 edição).

GAUDREAULT, André; MARION, Phillipe. La fin du Cinéma? Un média en crise à l'ére du numerique. Paris: Armand Colin, 2013. Campinas: Papirus, 2016 (no prelo).

MACHADO, Arlindo. Pré-Cinema \& Pós-Cinema. Campinas: Papirus, 1997.

MACIEL, Katia (org.) Transcinemas. Rio de Janeiro: Contra Capa, 2009.

MANOVICH, Lev. The language of new media. Cambridge: MIT Press, 2001

MULVEY, Laura. Death 24x a second - stilness and the moving image. Londres: Reaktion Books, 2006.

PAÏNI, Dominique. Le temps exposé - le cinéma, de la salle au musée. Paris: Cahiers du Cinéma, 2002.

RANCIÈRE, Jacques. A Fábula cinematográfica. Campinas: Papirus, 2013.

RODOWICK, David. The virtual life of film. Cambridge: Harvard University Press, 2007. . L'Événement Numérique. TRAFIC n79/ outono 2011.

YOUNGBLOOD, Gene. Expanded Cinema. Nova York: P.Dutton\&Co, 1970.

ROYOUX, Jean-Christophe. Pour un cinéma d'exposition. Retour sur quelques jalons historiques. OMNIBUS, 20, abril 1997. 